\title{
Detection of critical congenital heart disease among newborns in Argentina through the national surveillance system of congenital heart disease (RENAC)
}

\author{
Boris Groisman ${ }^{a, b}$ (D), Pablo Barbero ${ }^{a}$ (D), Rosa Liascovich Lib (D) Paloma Brun $^{a, c}$, \\ María P. Bidondo, ${ }^{a, d}$ (D)
}

\begin{abstract}
Introduction. Critical congenital heart disease (CCHD) is a term that refers to ductus-dependent structural anomalies of the heart that may be fatal or require invasive management in the first month of life.

Objective. To know the prevalence and distribution of CCHD among newborns in Argentina, compared to other countries, and the proportion of prenatal detection and perinatal mortality.
\end{abstract}

a. National Network of Congenital Anomalies (Red Nacional de Anomalias Congénitas de Argentina, RENAC). National Administration of Health Institutes and Labs "Dr. Carlos G. Malbrán," Argentina.

b. National Scientific and Technical Research Council (Consejo Nacional de Investigaciones Científicas y Técnicas, CONICET),

Argentina.

c. Rare Diseases and Congenital Anomalies National Program, National Ministry of Health, Argentina.

d. School of Medicine, Universidad de Buenos Aires (UBA), Argentina.

E-mail address:

Boris Groisman:

bgroisman@gmail.com

Funding:

None.

Conflict of interest:

None.

Received: 1-29-2021

Accepted: 5-18-2021 Bidondo MP. Detection of critical congenital heart disease among newborns in Argentina through the national surveillance system of congenital heart disease (RENAC). Arch Argent Pediatr 2022;120(1):6-13.

\section{INTRODUCTION}

Congenital heart disease (CHD) is in the group of most frequent congenital anomalies; ${ }^{1}$ given its severity, it is the leading cause of death due to congenital anomalies ${ }^{2}$ and up to $10 \%$ of all infant deaths are attributed to it. ${ }^{3}$

Critical CHD (CCHD) is a term that refers to ductus-dependent structural anomalies of the heart that may be fatal or require invasive procedures (cardiac catheterization or surgery) in the first 28 days of life. ${ }^{3}$ Most CCHD cases can be treated, but a poor clinical condition at the time of surgery increases mortality. ${ }^{2}$ Early detection is necessary to reduce morbidity and mortality; to achieve this objective there are two possible interventions: prenatal diagnosis and screening with pulse oximetry.

In 2018, infant mortality in Argentina was 8.9 every 1,000 livebirths and congenital anomalies accounted for $28 \%$ of these deaths. ${ }^{4}$ In a prior study, CHD was the leading cause of death due to congenital anomalies. ${ }^{5}$

The objectives of this study were to know the prevalence of CCHD among newborns reported by the National Network of Congenital Anomalies (Red Nacional de Anomalías Congénitas de Argentina, RENAC) — at a national level, by jurisdiction and by type of institution at birth - and the proportion of cases detected in the prenatal period and to compare these results to those reported in other countries.

\section{MATERIAL AND METHODS}

Descriptive, cross-sectional study. Data from the RENAC corresponding 
to the period between 11-01-2009 and 12-312018 were used. RENAC is the national system of hospital surveillance for major structural congenital anomalies, which operates since 2009 in maternity hospitals across the 24 jurisdictions of Argentina. A total of 161 health institutions are currently part of the RENAC: 135 from the public subsector and 26 from the private and health insurance subsector, with a coverage of approximately 280000 births per year, which accounts for $39 \%$ of all births in Argentina. The representatives of RENAC at each facility are mostly neonatologists who provide a monthly report to the coordination area following a standardized methodology. Reports include a description of cases and a set of variables, as well as the total number of births in each hospital. ${ }^{6}$ Each case is coded by the coordination area based on the International Classification of Diseases, $10^{\text {th }}$ revision (ICD-10) as modified by the Royal College of Pediatrics and Child Health. The RENAC includes all livebirths and stillbirths in whom a congenital anomaly is detected at the facility until their discharge, death or referral to the maternity center.

Livebirths and stillbirths with the following CCHD were selected for this study: hypoplastic left heart syndrome (Q23.4), coarctation of aorta (Q25.1), interruption of aortic arch (Q25.2), tricuspid atresia (Q22.41), pulmonary atresia with intact ventricular septum (Q22.00), tetralogy of Fallot (Q21.3), transposition of great arteries (Q20.3), common arterial trunk (Q20.0), double outlet right ventricle (DORV) (Q20.1), total anomalous pulmonary venous return (Q26.2), Ebstein's anomaly (Q22.5), and single ventricle (Q20.4). The prevalence at birth for the country and by jurisdiction was estimated. Prevalence was measured as the proportion of cases out of the total number of births in participating facilities, with a $95 \%$ confidence interval (CI), based on the Poisson distribution, using the STATA $12 \AA$ software.

In addition, the proportion of cases with CCHD with prenatal detection (PND) was estimated in the 2013-2018 period because this variable had not been initially included in the RENAC reports. The percentage of perinatal deaths was analyzed, which was calculated as the sum of all stillbirths and livebirths with CCHD deceased before discharge out of the total number of CCHD cases.

The trend in the prevalence of CCHD and PND was assessed with a $\chi^{2}$ test for trend, with an alpha level $=0.05$.
The total number of newborns with CCHD per year in Argentina was estimated extrapolating the reported prevalence to the total number of births in Argentina in 2018 as indicated in vital statistics reports. ${ }^{4}$

Based on clinical presentation, cases were classified as follows: a) isolated: if the patient had one or more CCHDs not associated with any other major, extracardiac congenital anomaly; b) multiple: if the patient had one or more CCHDs associated with any other major, extracardiac congenital anomaly or known associated condition (e.g., VACTER sequence) without a definite etiology, and c) syndromic: if the patient had one or more CCHDs with a known, genetic or environmental, etiology.

Results were compared to data from other systems for the surveillance of congenital anomalies: the National Birth Defects Prevention Network (NBDPN), ${ }^{7}$ the European Surveillance of Congenital Anomalies (EUROCAT) ${ }_{1}^{8}$ and the Bogotá Registry of Colombia. ${ }^{9}$ The NBDPN is a network of USA state registries. The EUROCAT is the network of European population registries of congenital anomalies. The Bogotá Registry uses the case and control methodology based on 7 hospitals in that city. To compare the data provided by the RENAC, the NBDPN, the EUROCAT, and the Bogotá Registry, prevalence ratios (PRs) were used, estimated as the ratio between the prevalence of CCHD according to the RENAC and the prevalence of CCHD according to the other registries.

\section{RESULTS}

During the period between October 2009 and December 2018, 2202994 newborns from the participating health care facilities were assessed; 2525 cases of CCHD were detected, thus resulting in a prevalence of 11.46 per 10000 births (95\% CI: 11.02-11.92). Based on such prevalence, the total number of newborns with CCHD per year in Argentina was estimated at 775 .

Based on the clinical presentation, 1814 (71.84\%) corresponded to isolated cases; 519 $(20.55 \%)$, to multiple cases; and $192(7.60 \%)$ were part of a syndrome.

The prevalence of CCHD and PND was significantly lower in the public subsector, whereas perinatal mortality was slightly higher in this subsector, but not statistically significant (Table 1).

No clear trend was observed in the prevalence of CCHD at birth (2009-2018 period) in both 
subsectors ( $\chi^{2}$ test for trend $\left.p>0.05\right)$. The trend in the percentage of PND (2013-2018 period) in both the public and private and trade union health insurance subsectors has increased ( $\chi^{2}$ test for trend $p<0.05$ (Figure 1).

There was heterogeneity among jurisdictions in terms of prevalence, perinatal mortality, and the percentage of PND (Table 2).

Tetralogy of Fallot was the most common specific CCHD. Ebstein's anomaly was the most common specific CCHD observed in isolation, whereas DORV was the CCHD most frequently associated with a syndrome or multiple anomalies (Table 3).

The prevalence of CCHD according to the RENAC was approximately $50 \%$ of that observed in the United States (NBDPN) and Europe (EUROCAT) (Table 4). In relation to specific
CCHD, they were also all more common in these registries, except for Ebstein's anomaly (higher than in the EUROCAT) and single ventricle (higher than in the NBDPN). Compared to the Bogotá Registry, the RENAC showed a significantly higher prevalence of hypoplastic left heart syndrome and a significantly lower prevalence of coarctation of aorta and pulmonary atresia.

\section{DISCUSSION}

This study detected a higher prevalence of CCHD in the health insurance subsector than in the public one. The percentage of PND of CCHD was $43.93 \%$, which is lower than that observed in other countries; ${ }^{10}$ in addition, a higher percentage of PND was recorded in facilities working with the private and trade union health insurance subsector.

TABLE 1. Prevalence, prenatal detection, and perinatal deaths due to critical congenital heart disease by subsector (RENAC, 2013-2018)

\begin{tabular}{lccc}
\hline Subsector & Public & Private and TU health insurance & Total \\
\hline Prevalence $\times 10000(95 \%$ CI) & 11.07 & 16.53 & 11.46 \\
Prenatal detection (\%) & $(10.56-11.61)$ & $(14.83-18.38)^{* *}$ & $(11.02-11.92)$ \\
Perinatal deaths $(\%)^{*}$ & 39.82 & 64.91 & 43.93 \\
\hline
\end{tabular}

* Stillbirths + live newborns deceased before discharge from maternity center.

** Statistically significant difference $(p<0.05)$.

RENAC: National Network of Congenital Anomalies; TU: trade union; CI: confidence interval.

FIGURE 1. Prenatal detection of critical congenital heart disease by subsector (2013-2018)

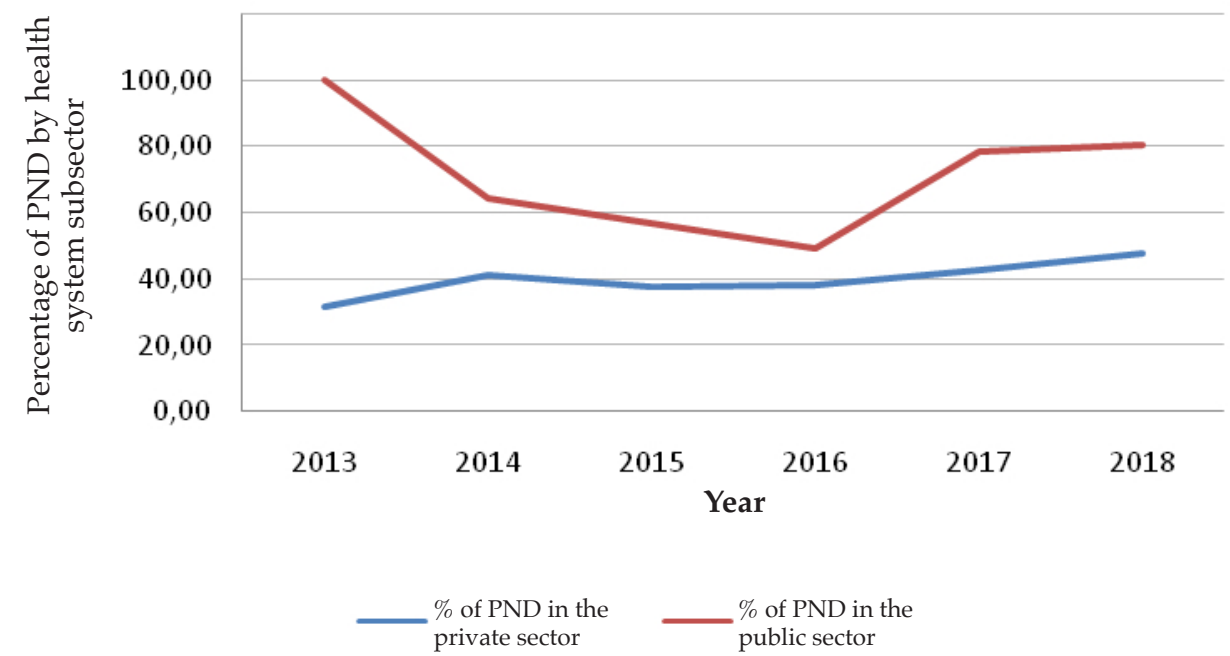

PND: prenatal detection. 
TABLE 2. Prevalence, perinatal deaths and prenatal detection of critical congenital heart disease by jurisdiction (RENAC, 2009-2018)

\begin{tabular}{|c|c|c|c|c|c|c|}
\hline \multirow{2}{*}{$\begin{array}{l}\text { Jurisdiction } \\
\text { Buenos Aires }\end{array}$} & \multirow{2}{*}{$\begin{array}{c}\begin{array}{c}\text { Cases of } \\
\text { CCHD (n) }\end{array} \\
790\end{array}$} & \multirow{2}{*}{$\begin{array}{l}\text { Births } \\
673683\end{array}$} & \multicolumn{2}{|c|}{$\begin{array}{c}\text { Prevalence } \times 10000 \\
(95 \% \text { CI })\end{array}$} & \multirow{2}{*}{$\begin{array}{c}\begin{array}{c}\text { Perinatal } \\
\text { deaths }(\%)\end{array} \\
21.65\end{array}$} & \multirow{2}{*}{$\begin{array}{c}\text { PND (\%) } \\
41.09\end{array}$} \\
\hline & & & 11.73 & $10.92-12.57$ & & \\
\hline CABA & 474 & 303329 & 15.63 & $14.25-17.10$ & 23.63 & 62.28 \\
\hline Catamarca & 22 & 22478 & 9.79 & $6.13-14.82$ & 18.18 & 5.56 \\
\hline Chaco & 48 & 78407 & 6.12 & $4.51-8.12$ & 27.08 & 44.12 \\
\hline Chubut & 26 & 26176 & 9.93 & $6.49-14.55$ & 11.54 & 4.00 \\
\hline Córdoba & 174 & 111235 & 15.64 & $13.40-18.15$ & 22.99 & 63.76 \\
\hline Corrientes & 39 & 41090 & 9.49 & $6.75-12.98$ & 38.46 & 11.43 \\
\hline Entre Ríos & 47 & 47855 & 9.82 & 7.22-13.06 & 19.15 & 13.16 \\
\hline Formosa & 12 & 32732 & 3.67 & $1.89-6.40$ & 41.67 & 33.33 \\
\hline Jujuy & 38 & 52558 & 7.23 & $5.12-9.92$ & 36.84 & 29.63 \\
\hline La Pampa & 18 & 13420 & 13.41 & $7.95-21.20$ & 22.22 & 16.67 \\
\hline La Rioja & 24 & 23020 & 10.43 & $6.68-15.51$ & 37.50 & 18.18 \\
\hline Mendoza & 101 & 86867 & 11.63 & $9.47-14.13$ & 14.85 & 32.94 \\
\hline Misiones & 95 & 95386 & 9.96 & $8.06-12.18$ & 29.47 & 34.62 \\
\hline Neuquén & 38 & 36640 & 10.37 & $7.34-14.24$ & 34.21 & 38.89 \\
\hline Río Negro & 21 & 20234 & 10.38 & $6.42-15.86$ & 9.52 & 31.25 \\
\hline Salta & 102 & 105738 & 9.65 & $7.87-11.71$ & 41.18 & 40.51 \\
\hline San Juan & 55 & 56245 & 9.78 & $7.37-12.73$ & 29.09 & 23.91 \\
\hline San Luis & 23 & 27664 & 8.31 & $5.27-12.48$ & 34.78 & 61.11 \\
\hline Santa Cruz & 16 & 11240 & 14.23 & $8.14-23.12$ & 18.75 & 7.69 \\
\hline Santa Fe & 159 & 148183 & 10.73 & $9.13-12.53$ & 28.3 & 45.52 \\
\hline Santiago del Estero & 40 & 51469 & 7.77 & $5.55-10.58$ & 42.5 & 19.23 \\
\hline Tierra del Fuego & 11 & 9136 & 12.04 & $6.01-21.54$ & 0 & 33.33 \\
\hline Tucumán & 152 & 128209 & 11.86 & $10.05-13.9$ & 28.95 & 52.59 \\
\hline Total & 2525 & 2202994 & 11.46 & $11.02-11.92$ & 25.03 & 43.93 \\
\hline
\end{tabular}

RENAC: National Network of Congenital Anomalies; CABA: Autonomous City of Buenos Aires;

CCHD: critical congenital heart disease; PND: prenatal detection; CI: confidence interval.

TABLE 3. Prevalence, clinical presentation, and prenatal detection of critical congenital heart disease (RENAC, 2009-2018)

\begin{tabular}{|c|c|c|c|c|c|c|}
\hline \multirow{2}{*}{$\begin{array}{l}\text { Critical congenital } \\
\text { heart disease }\end{array}$} & \multirow{2}{*}{$\begin{array}{l}\text { No. of } \\
\text { cases }\end{array}$} & \multirow{2}{*}{$\begin{array}{c}\text { Prevalence } \times 100000 \\
(95 \% \mathrm{CI})\end{array}$} & \multicolumn{3}{|c|}{ Clinical presentation $(\%)$} & \multirow[t]{2}{*}{$\%$ PND $^{*}$} \\
\hline & & & Isolated & Multiple & Syndromic & \\
\hline Tetralogy of Fallot & 435 & $19.75(17.93-21.69)$ & 64.37 & 22.76 & 12.87 & 32.87 \\
\hline Transposition of great vessels & 428 & $19.43(17.63-21.36)$ & 80.84 & 14.95 & 4.21 & 28.97 \\
\hline Coarctation of aorta & 417 & $18.93(17.16-20.84)$ & 70.98 & 21.34 & 7.67 & 26.62 \\
\hline Hypoplastic left heart syndrome & 402 & $18.25(16.51-20.12)$ & 76.87 & 17.41 & 5.72 & 53.73 \\
\hline Single ventricle & 261 & $11.85(10.45-13.38)$ & 68.2 & 24.90 & 6.90 & 44.06 \\
\hline Ebstein's anomaly & 136 & $6.17(5.18-7.30)$ & 90.44 & 5.15 & 4.41 & 48.53 \\
\hline Double outlet right ventricle & 135 & $6.13(5.14-7.25)$ & 50.37 & 35.56 & 14.07 & 42.96 \\
\hline Persistent truncus arteriosus & 84 & $3.81(3.04-4.72)$ & 65.48 & 25.00 & 9.52 & 29.76 \\
\hline Interruption of aortic arch & 77 & $3.50(2.76-4.37)$ & 66.23 & 23.38 & 10.39 & 27.27 \\
\hline Pulmonary atresia & 77 & $3.50(2.76-4.37)$ & 85.71 & 14.29 & 0 & 35.06 \\
\hline Tricuspid atresia & 75 & $3.40(2.68-4.27)$ & 81.33 & 17.33 & 1.33 & 53.33 \\
\hline Aortic stenosis & 68 & $3.09(2.40-3.91)$ & 77.94 & 17.65 & 4.41 & 32.35 \\
\hline Tricuspid stenosis & 52 & $2.36(1.76-3.10)$ & 86.54 & 11.54 & 1.92 & 23.08 \\
\hline $\begin{array}{l}\text { Total anomalous pulmonary } \\
\text { venous return }\end{array}$ & 49 & $2.22(1.65-2.94)$ & 79.59 & 20.41 & 0 & 22.45 \\
\hline
\end{tabular}

* For the estimation of prenatal detection, available data covered the 2013-2018 period.

RENAC: National Network of Congenital Anomalies; PND: prenatal detection; CI: confidence interval. 
The fact that the prevalence of CCHD reported by the RENAC was lower than in the United States and European registries, with differences above $50 \%$, may indicate that a relevant proportion of CCHD cases in newborns remained undetected by our surveillance system. Ebstein's anomaly showed a higher prevalence in the RENAC than in the European registries. The etiology of Ebstein's anomaly is unknown, although it has been associated with environmental factors. ${ }^{11,12}$ When comparing the prevalence of specific CCHD between the RENAC and the Bogotá Registry, no statistically significant difference was observed in most heart diseases.
At this point, it is necessary to underscore that surveillance systems for congenital anomalies of different parts of the world have varying case definitions and work methodologies. One of the most relevant aspects is the age at the time of detection. Hospital-based systems like the RENAC and the Bogotá Registry only detect anomalies at birth, whereas others include cases detected subsequently, even until 6 years old. Most systems that are part of the EUROCAT and the NBDPN also have multiple sources of data, not only maternity centers, such as children's hospitals, specialty offices, etc. The RENAC works at a national level and has a broad coverage but

TABLE 4. Prevalence of critical congenital heart disease per 100000 births according to different registries and comparison with the RENAC (2009-2018)

\begin{tabular}{|c|c|c|c|c|c|c|c|c|c|c|c|}
\hline \multirow{2}{*}{$\begin{array}{l}\text { Critical } \\
\text { congenital } \\
\text { heart disease } \\
\text { Coarctation of aorta }\end{array}$} & \multicolumn{2}{|c|}{$\begin{array}{c}\text { RENAC } \\
\text { Prevalence }(\%) \text {, } \\
\text { 95\% CI }\end{array}$} & \multicolumn{2}{|c|}{$\begin{array}{c}\text { EUROCAT }^{1} \\
\text { Prevalence }(\%), \\
95 \% \text { CI }\end{array}$} & \multirow{2}{*}{$\begin{array}{c}\text { PR } \\
1.84^{*}\end{array}$} & \multicolumn{2}{|c|}{$\begin{array}{c}\text { NBDPN }^{2} \\
\text { Prevalence }(\%), \\
95 \% \text { CI }\end{array}$} & \multirow{2}{*}{$\begin{array}{l}\text { PR } \\
2.93^{*}\end{array}$} & \multicolumn{2}{|c|}{$\begin{array}{c}\text { Bogotá, Colombia } \\
\text { Prevalence }(\%), \\
95 \% \mathrm{CI}\end{array}$} & ${ }^{3}$ PR \\
\hline & 18.93 & $17.16-20.84$ & 34.8 & $33.6-35.9$ & & 55.5 & $53.4-57.5$ & & 51.83 & $39.84-66.62$ & $2.74^{*}$ \\
\hline \multicolumn{12}{|l|}{ Hypoplastic left } \\
\hline heart syndrome & 18.25 & $16.51-20.12$ & 23.0 & $22.1-24.0$ & $1.26^{*}$ & 26.1 & $24.7-27.5$ & $1.43^{*}$ & 1.7 & $0.20-6.06$ & $0.09^{*}$ \\
\hline Tetralogy of Fallot & 19.75 & $17.93-21.69$ & 31.0 & $30.0-32.1$ & $1.57^{\star}$ & 46 & $44.2-47.9$ & $2.33^{*}$ & 18.41 & $11.56-27.92$ & 0.93 \\
\hline $\begin{array}{l}\text { Transposition of } \\
\text { great vessels }\end{array}$ & 19.43 & $17.63-21.36$ & 29.3 & $28.2-30.3$ & $1.51^{*}$ & 38 & $36.3-39.8$ & $1.96^{*}$ & 14.2 & $8.30-22.81$ & 0.73 \\
\hline $\begin{array}{l}\text { Persistent truncus } \\
\text { arteriosus }\end{array}$ & 3.81 & $3.04-4.72$ & 6.5 & $6.0-7.0$ & $1.7^{*}$ & 6.7 & $6.0-7.4$ & $1.76^{*}$ & 2.5 & $0.52-7.35$ & 0.66 \\
\hline Single ventricle & 11.85 & $10.45-13.38$ & 6.7 & $6.2-7.2$ & $1.77^{\star}$ & 7.9 & $7.2-8.8$ & $0.67^{*}$ & 12.5 & 7.04-20.74 & 1.06 \\
\hline Tricuspid stenosis & 2.36 & $1.76-3.10$ & 5.5 & $5.1-6.0$ & $2.33^{*}$ & NR & NR & NR & NR & NR & NR \\
\hline Tricuspid atresia & 3.40 & $2.68-4.27$ & 5.5 & $5.1-6.0$ & $1.62^{*}$ & 10.1 & $9.2-11.0$ & $2.97^{*}$ & NR & NR & NR \\
\hline Aortic stenosis & 3.09 & $2.40-3.91$ & 14.9 & $14.2-15.7$ & $4.83^{*}$ & NR & NR & NR & NR & NR & NR \\
\hline Ebstein's anomaly & 6.17 & $5.18-7.30$ & 4.2 & $3.8-4.6$ & $0.68^{*}$ & 7.9 & $7.2-8.7$ & 1.28 & NR & NR & NR \\
\hline $\begin{array}{l}\text { Interruption } \\
\text { of aortic arch }\end{array}$ & 3.50 & $2.76-4.37$ & 4.2 & $3.7-4.7$ & 1.2 & 6.2 & $5.5-7.0$ & $1.77^{*}$ & 1.7 & $0.20-6.06$ & 0.49 \\
\hline Pulmonary atresia & 3.50 & $2.76-4.37$ & 9.2 & $8.6-9.8$ & $2.63^{*}$ & 14.3 & $13.3-15.4$ & $4.09^{*}$ & 15 & 8.94-23.84 & $4.29^{*}$ \\
\hline $\begin{array}{l}\text { Total anomalous pul } \\
\text { venous return }\end{array}$ & 2.22 & $1.65-2.94$ & 5.3 & $4.9-5.8$ & $2.38^{*}$ & 13.9 & $12.9-15.0$ & $6.25^{*}$ & 5.8 & $2.36-12.09$ & 2.61 \\
\hline $\begin{array}{l}\text { Double outlet } \\
\text { right ventricle }\end{array}$ & 6.13 & 5.14-7.25 & 12.5 & $11.8-13.3$ & $2.04^{*}$ & 16.9 & $5.8-18.1$ & 2.76 & NR & NR & NR \\
\hline Total heart diseases & 109.4 & $104.8-114.0$ & 201.0 & $198.2-203.8$ & $1.75^{\star}$ & 199.3 & $197.4-201.3$ & $1.74^{*}$ & NR & NR & NR \\
\hline
\end{tabular}

RENAC: National Network of Congenital Anomalies; EUROCAT: European Surveillance of Congenital Anomalies;

NBDPN: National Birth Defects Prevention Network; NR: not reported; PR: prevalence ratio (considering the RENAC as reference); ${ }^{*} p<0.05$.

${ }^{1}$ EUROCAT (Europe). Prevalence charts and tables. Data for 2010-2017. [Accessed on: July $8^{\text {th }}$, 2021]. Available at: https: / / eu-rdplatform.jrc.ec.europa.eu/eurocat/eurocat-data/prevalence_en

${ }^{2}$ Mai CT, Isenburg JL, Canfield MA, Meyer RE, et al. National population-based estimates for major birth defects, 2010-2014. Birth Defects Res. 2019;111(18):1420-35.

${ }^{3}$ Puentes Mahecha SJ, Zarante I, Madariaga I. Programa de vigilancia de malformaciones congénitas en la ciudad de Bogotá D.C.: estadística anual 2019. [Accessed on: July $8^{\text {th }}$, 2021]. Available at: http:/ / www.anomaliascongenitas.org/app/webroot/ blog/wp-content/uploads / 2020/04/Informe-Anual-2019.pdf 
records only identifiable congenital anomalies until discharge from the maternity ward.

Such methodological aspects partially explain the differences among the registries. Particularly, newborns with CCHD may not show clinical manifestations in the first days of life and therefore, remained undetected by the surveillance system. In addition, the lower prevalence is possibly associated with the low PND observed here.

In our study, the prevalence across jurisdictions was heterogeneous, which is probably associated with a dissimilar availability of pediatric cardiologists and supplementary diagnostic methods. In turn, in most cases, CCHD was isolated, which is consistent with what has been previously reported..$^{11}$ The CCHD most commonly associated with syndromic or multiple conditions was DORV, whereas Ebstein's anomaly was the most common isolated CCHD; both outcomes are consistent with the bibliography. ${ }^{12,13}$ Syndromic conditions were more common in conotroncal heart diseases, which is explained by the association of such heart diseases with prevalent entities, such as a 22q11 deletion and Down syndrome, among others. ${ }^{11}$

In our study, perinatal mortality was $25 \%$. The mortality reported in other studies varies based on different aspects: age of patients, inclusion of highly lethal conditions, countries with or without legal abortion laws, etc. ${ }^{14-17} \mathrm{~A}$ study conducted in Texas, that excluded highly lethal syndromic conditions (trisomy 13 and 18), detected 2360 newborns with CCHD; of these, $13.18 \%$ died in the first month of life..$^{14} \mathrm{~A}$ study conducted in Malaysia between 2006 and 2015 in newborns with CCHD found that $17 \%$ died before undergoing surgery, and at 1 year old, mortality increased to $34.8 \% .{ }^{17}$

The early detection of CCHD is key to reduce morbidity and mortality ${ }^{3}$ and may be done in the antenatal controls or during the newborn clinical examination. The search for signs such as murmur and weak pulse is often not done in the early postnatal period, and the presence of cyanosis is frequently not detected during clinical examination. ${ }^{2}$ It has been estimated that up to 30\% of newborns with CCHD are discharged without being diagnosed; ${ }^{3}$ in this group of patients, mortality may reach $50 \% .{ }^{18}$ A delayed diagnosis of CCHD has been associated with a higher mortality rate. ${ }^{14}$

A measure that would allow the early detection of CCHD is the universal implementation of a pulse oximetry in newborns before being discharged from the maternity ward. Currently, several countries have implemented CCHD screening using pulse oximetry, ${ }^{20-24}$ a test that has proven to be cost-effective. ${ }^{25}$ The test to detect a (ductus-dependent) CCHD consists in measuring preductal saturation (right hand) and postductal saturation (foot); when compared, a difference in saturation may be observed in association with this type of heart disease. Through a simple and bloodless method, a high rate of asymptomatic newborns with CCHD may be detected. The test has shown to be highly specific, moderately sensitive, and with a low rate of false positive results. ${ }^{26}$

Although a well-known recommendation is to perform a fetal cardiac assessment during the routine detailed ultrasound done in all pregnancies between weeks 20 and $24,27,28$ our study showed that the percentage of PND of CCHD cases is still low and that there are big differences between health system sectors. An improvement in PND would allow to refer patients to a facility with a higher level of care; therefore, it is suggested to promote training among health care providers who perform ultrasounds in pregnant women so that they are able to detect CHD.

In Argentina, the problem caused by CHD morbidity and mortality has been recognized for some time now..$^{29-31}$ In 2008, the National Heart Disease Program ${ }^{32}$ was launched for the purpose of warranting the surgical resolution of children with CHD across the country. For some time, Argentine departments of neonatology have used pulse oximetry as part of the monitoring of hospitalized newborns. ${ }^{33}$ In turn, the pulse oximetry as a screening method for all newborns has been indicated in 2015 as recommendation of the National Directorate of Maternity and Childhood of the Ministry of Health. ${ }^{34}$ More recently, a draft bill was proposed to make a pulse oximetry mandatory in newborn screening. However, to date, it has not been made mandatory in Argentina. Since asymptomatic newborns may be discharged from the maternity ward without being diagnosed, the suggestion is to implement a postnatal pulse oximetry as a mandatory and universal screening test for all newborns in Argentina in order to warrant the timely detection of CCHD and reduce related morbidity and mortality.

This study poses certain limitations. The RENAC is not a population registry; therefore, 
the estimated prevalence of CCHD is the result of a proportion out of the total number of births occurred in the country (39\% of all newborns). Such percentage of coverage is higher in public health care facilities than in those working in the private and health insurance sectors; therefore, values across the different country jurisdictions are heterogeneous. Another limitation of this study was that it did not include CCHD cases detected after discharge from the maternity ward.

\section{CONCLUSION}

When compared to other countries, the prevalence of CCHD and PND in Argentina were both low. Given that prenatal and postnatal detection of CCHD is a major determinant of health outcomes among affected subjects, these findings probably account for the high morbidity and mortality still persistent in this prevalent group of congenital anomalies.

\section{Acknowledgments}

We would like to thank all RENAC members for making this study possible.

\section{REFERENCES}

1. van der Linde D, Konings EE, Slager MA, Witsenburg M, et al. Birth prevalence of congenital heart disease worldwide: a systematic review and meta-analysis. J Am Coll Cardiol. 2011; 58:2241-7.

2. Mahle WT, Newburger JW, Matherne GP, Smith FC, et al. Role of pulse oximetry in examining newborns for congenital heart disease: a scientific statement from the AHA and AAP. Pediatrics. 2009; 124(2):823-36.

3. Wren C, Reinhardt Z, Khawaja K. Twenty-year trends in diagnosis of life-threatening neonatal cardiovascular malformations. Arch Dis Child Fetal Neonatal Ed. 2008; 93(1):F33-5.

4. Dirección de Estadísticas e Información de Salud (DEIS), Estadísticas Vitales, Información Básica Año 2018. 5(62) [Accessed on:December 19 $9^{\text {th }}$, 2020]. Available at: www.deis. msal.gov.ar/wp-content/uploads/2020/01/Serie5Nro62. pdf

5. Finkelstein J, Duhau M, Speranza A, Marconi E, Escobar P. Evolución de la mortalidad infantil en Argentina en el marco de los Objetivos de Desarrollo del Milenio. Arch Argent Pediatr. 2016; 114(3):216-22.

6. Groisman B, Bidondo MP, Barbero P, GiliJA, et al. RENAC: Registro Nacional de Anomalías Congénitas de Argentina. Arch Argent Pediatr. 2013; 111(6):484-94.

7. MaiCT, Isenburg JL, Canfield MA, Meyer RE, et al. National population-based estimates for major birth defects, 20102014. Birth Defects Res. 2019; 111(18):1420-35.

8. Boyd PA, Haeusler M, Barisic I, Loane M, et al. Paper 1: TheEUROCAT network--organization and processes. Birth Defects Res A Clin Mol Teratol. 2011; 91(Suppl 1):S2-15.

9. Zarante M, Sarmiento K, Mallarino C, Gracia G. Description of Bogotá birth defects surveillance and follow-up program. J Registry Manag. 2016; 41(3):116-21.

10. van Velzen CL, Ket JCF, van de Ven PM, Blom NA, Haak MC. Systematic review and meta-analysis of the performance of second-trimester screening for prenatal detection of congenital heart defects. Int J Gynaecol Obstet. 2018; 140(2):137-45.

11. Stevenson RE, Hall JH, Everman D, Solomon B. Human malformation and related Anomalies. $3^{\text {rd }}$ ed. New York: Oxford University Press; 2016.

12. Downing KF, Riehle-Colarusso T, Gilboa SM, Lin AE, et al. Potential risk factors for Ebstein anomaly, National Birth Defects Prevention Study, 1997-2011. Cardiol Young. 2019; 29(6):819-27.

13. Obler D, Juraszek AL, Smoot LB, Natowicz MR. Double outlet right ventricle: aetiologies and associations. J Med Genet. 2008; 45(8):481-97.

14. Fixler DE, Xu P, Nembhard WN, Ethen MK, Canfield MA. Age at referral and mortality from critical congenital heart disease. Pediatrics. 2014; 134(1):e98-105.

15. Eckersley L, Sadler L, Parry E, Finucane K, Gentles TL. Timing of diagnosis affects mortality in critical congenital heart disease. Arch Dis Child. 2016; 101(6):516-20.

16. Campbell MJ, Quarshie WO, Faerber J, Goldberg DJ, et al. Pulse Oximetry Screening Has Not Changed Timing of Diagnosis or Mortality of Critical Congenital Heart Disease. Pediatr Cardiol. 2020; 41(5):899-904.

17. Mat Bah MN, Sapian MH, Jamil MT, Alias A, Zahari N. Survival and Associated Risk Factors for Mortality Among Infants with Critical Congenital Heart Disease in a Developing Country. Pediatr Cardiol. 2018; 39(7):1389-96.

18. Chang RK, Gurvitz M, Rodriguez S. Missed diagnosis of critical congenital heart disease. Arch Pediatr Adolesc Med. 2008; 162(10):969-74.

19. Lloyd-Jones D, Adams R, Carnethon M, De Simone G, et al. Heart disease and stroke statistics - 2009 update: a report from the American Heart Association Statistics Committee and Stroke Statistics Subcommittee. Circulation . 2009; 119(3):480-6.

20. de-Wahl Granelli A, Meberg A, Ojala T, Steensberg J, et al. Nordic pulse oximetry screening - implementation status and proposal for uniform guidelines. Acta Paediatr. 2014; 103(11):1136-42.

21. Kuelling B, Arlettaz Mieth R, Bauersfeld U, Balmer C. Pulse oximetry screening for congenital heart defects in Switzerland: most but not all maternity units screen their neonates. Swiss Med Wkly. 2009; 139(47-48):699-704.

22. Mahle WT, Martin GR, Beekman RH 3rd, Morrow WR. Endorsement of Health and Human Services recommendation for pulse oximetry screening for critical congenital heart disease. Pediatrics. 2012; 129(1):190-2.

23. Manzoni P, Martin GR, Sanchez Luna M, Mestrovic J, et al. Pulse oximetry screening for critical congenital heart defects: a European consensus statement. Lancet Child Adolesc Health. 2017; 1(2):88-90.

24. Sánchez Luna M, Pérez Muñuzuri A, Sanz López E, Leante Castellanos L, et al. Cribado de cardiopatías congénitas críticas en el periodo neonatal. Recomendación de la Sociedad Española de Neonatología. An Pediatr (Engl Ed). 2018; 88(2):112.e1-6.

25. Peterson C, GrosseSD, OsterME, Olney RS, CassellCH. Costeffectiveness of routine screening for critical congenital heart disease in US newborns. Pediatrics. 2013; 132(3):e595-603. 26.

26. Plana MN, Zamora J, Suresh G, Fernández-Pineda L, et al. Pulse oximetry screening for critical congenital heart defects. Cochrane Database Syst Rev. 2018; 3(3):CD011912.

27. International Society of Ultrasound in Obstetrics and Gynecology, Carvalho JS, Allan LD, Chaoui R, et al. ISUOG Practice Guidelines (updated): sonographic screening examination of the fetal heart. Ultrasound Obstet Gynecol. 2013; 41(3):348-59. 
28. Meller CH, Grinenco S, Aiello H, Córdoba A, et al. Cardiopatías congénitas, diagnóstico y manejo prenatal. Arch Argent Pediatr. 2020; 118(2):e149-61.

29. Sarrasqueta P, Basso G. Mortalidad postneonatal en la ciudad de Buenos Aires en 1987. Arch Argent Pediatr. 1988; 86(6):327-33.

30. López N, Ceriani Cernadas JM, Garcia Nani M. Cardiopatías congénitas en 356 recién nacidos observados en un período de 10 años. Arch Argent Pediatr. 1991; 89(2):69-74.

31. Magliola R, Laura J, Capelli H. Situación actual de los niños con cardiopatía congénita en Argentina. Arch Argent Pediatr. 2000; 98(2):130-3.

32. Argentina. Ministerio de Salud. Programa Nacional de Cardiopatías Congénitas [Accessed on: December 1 ${ }^{\text {st }}$,
2020] Available at: http://www.msal.gob.ar/index. $\mathrm{php}$ / programas-y-planes / 414-programa-nacional-decardiopatias-\%20congenitas-pncc

33. Salas G, Satragno D, Bellani P, Quiroga A, et al. Consenso sobre la monitorización del recién nacido internado. Parte 1: Monitorización no invasiva del recién nacido. Arch Argent Pediatr. 2013; 111(4):353-9.

34. Speranza A, Quiroga A, Ávila A, Fernández P, et al. Detección de Cardiopatías Congénitas por Oximetría de Pulso en recién nacidos asintomáticos. Buenos Aires: Dirección Nacional de Maternidad e Infancia, Ministerio de Salud; 2015. [Accessed on: May 28 ${ }^{\text {th }}$, 2021]. Available at: https: / / bancos.salud.gob.ar/sites / default/ files / 201810/0000000726cnt-deteccion-cardiopatias.pdf 